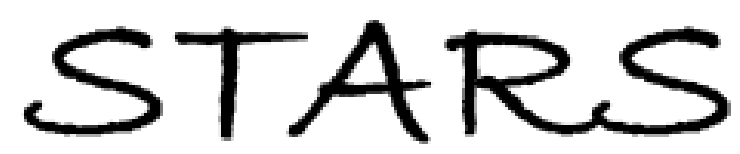

University of Central Florida

STARS

$1-19-2012$

\title{
Brand Management in the Hospitality Industry
}

David J. Kwun

University of Central Florida, David.Kwun@ucf.edu

Part of the Hospitality Administration and Management Commons, and the Tourism and Travel

\section{Commons}

Find similar works at: https://stars.library.ucf.edu/rosenscholar

University of Central Florida Libraries http://library.ucf.edu

This Paper is brought to you for free and open access by the Rosen College of Hospitality Management at STARS. It has been accepted for inclusion in Rosen Faculty Scholarship and Creative Works by an authorized administrator of STARS. For more information, please contact STARS@ucf.edu.

\section{Original Citation}

Kwun, D. J. (2012). Brand management in the hospitality industry. Journal of Tourism \& Hospitality, 1(1), $1-2$.

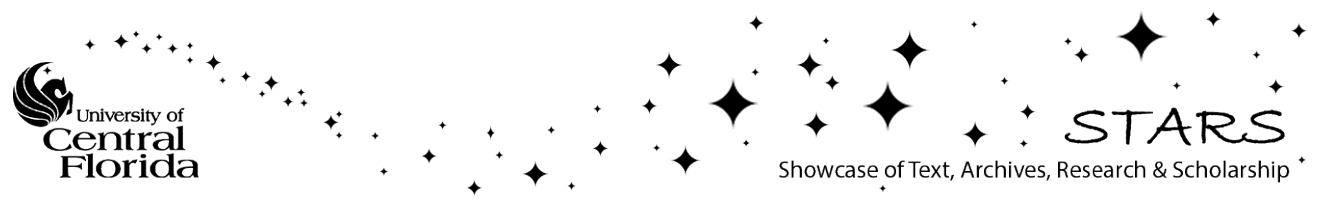




\section{Tourism \& Hospitality}

\section{Brand Management in the Hospitality Industry}

\section{David J Kwun*}

Rosen College of Hospitality Management, University of Central Florida, USA

One of a firm's essential assets is a well-established brand name that provides competitive advantages, both tangibles and intangibles, on its performance. Effective management of a brand creates an identity for products and services and differentiates them from its core competitors [1]. For that reason, building and managing strong brands have been considered a key driver of success in the hospitality industry. Kotler et al. [2] defined a brand as "a name, term, sign, symbol, design, or a combination of those elements intended to identify the goods and services of a seller and differentiate them from competitors" (p. 239). The primary focus of brand management was on identification of components (i.e., identify the source or makers of a product) until leading companies started to differentiate their products and services through a symbolic and elusive meaning system embedded under their brand names. The importance of brand management was further amplified when the greatest number of launching new brands, brand extensions, and product tiers occurred in the 1980s. This trend leads in an era of brand management research [3]. One reason for the explosion of new hotels and restaurants in this period was that the baby boomer generation entered its peak earning years with different lifestyles and increased number of dual income families.

This industry-wide trend has led to intensified competition, market saturation in some segments of the hospitality industry, and difficulty for consumers to comprehend and evaluate the large number of hotels and restaurants in the marketplace. Hospitality companies had to continuously reposition their brands and differentiate their product offering for sustained growth. In view of that, a small number of major hospitality companies have developed several different brands and formed brand portfolios, mainly through initiating brand extension and/or mergers and acquisition strategies. Currently, the number of brands among major lodging companies varies from less than ten brands like Intercontinental Hotel Group and Starwood Hotels and Resorts Worldwide to close to twenty brands like Wyndham Worldwide and Marriott Corporation. In the same way, leading restaurant companies (e.g., OSI Restaurant Partners, LLC and Darden Restaurants) possess more than five strong restaurant brands in their portfolios. Congruently, major hospitality companies are focusing on how to optimize synergies among their brands in their portfolios [4]. This trend of concentration of valuable brands in a few major brand portfolios is expected to continue in a global setting and will persistently change the industry structure.

The hospitality industry has entered a new cycle of brand management in the 2000s with new breeds of concepts and products. The launch of W Hotels from Starwood as a luxury boutique hotel concept had a massive impact on current trends in lifestyle hotel brands. Lodging companies are continuously introducing similar products (e.g., Aloft, Elements, Indigo, Edition, Andaz, etc.) while vertically restructuring their brand portfolios with more high-end and/ or experiential products. Likewise, the restaurant industry is following this similar trend. Many restaurants, especially in the quick service segments, went through a widespread re-branding and re-positioning phase with renewed logos, exterior and interior design, and expanded menus. The Darden Restaurants, Inc. (which owns Red Lobster, Olive Garden, Bahama Breeze, and Season 52) sold Smokey Bones and acquired Capital Grill and Longhorn Steakhouse in 2007. Recently, they announced they will add two upscale seafood restaurants in their brand portfolio in 2012. In addition, leading restaurant companies are initiating various branding strategies and introducing fast casual and ethnic cuisine concepts, which are broadly accepted among eatingout consumers. One of the latest branding trends in the hospitality industry has been expending a well-established name on a cluster of products or services (e.g., McDonald's McCafe and McTreat, Westin Hotels' Heavenly Bed and Shower, and W Hotels' Jewelry).

Effective and efficient management of a well-established brand name is persistently identified as one of the top priorities among researchers and industry practitioners [3,2,5]. King et al. [6] revealed that brand management is one of the relative alignments of hospitality research and industry priorities. Accordingly, brand proliferation and differentiation, brand loyalty and competitive advantageous, and delivering brand promise were highlighted as foremost brand management concerns when operating in a highly competitive market. Additionally, recent studies on brand management explored new dimensions of brand equity and transfer effects of brand associations with theoretical grounding and conceptual rigor that are uniquely attributable to the hospitality industry $[7,8]$. Due to advanced information technology, explosive impact of mobile devices, consolidated distribution systems, bifurcated demographic configuration of baby boomer and Generation Y, competitive and shifting market environment, and changes in socio-demographic characteristics and standard of living, major companies are expected to accelerate new and innovative branding strategies. To a greater extent, brand management became a long term strategic decision of a firm and will continuously advance to encompass from brand equity, brand extensions, co-branding, and market competitiveness to identity, personality, image, association, trust, and attitude that customers perceive.

\section{References}

1. Kapferer JN (1997) Strategic brand management. London: Kogan Page.

2. Kotler P, Bowen J, Makens J (2010) Marketing for Hospitality and Tourism (5 edn), Upper Saddle River, NJ: Prentice Hall.

3. Dev CS, Buschman JD, Bowen JT (2010) Hospitality marketing: A retrospective analysis (1960-2010) and predictions (2010-2020). Cornell Hospitality Quarterly 51: 459-469.

*Corresponding author: David J. Kwun, Assistant Professor, Department of Hospitality and Tourism Management, Rosen College of Hospitality Management University of Central Florida, USA, Tel: 407-903-8190; Fax: 407-903-8105; E-mail: David.Kwun@ucf.edu

Received January 12, 2012; Accepted January 16, 2012; Published January 19 2012

Citation: Kwun DJ (2012) Brand Management in the Hospitality Industry. J Tourism Hospit 1:e104. doi:10.4172/2167-0269.1000e104

Copyright: $\odot 2012$ Kwun DJ. This is an open-access article distributed under the terms of the Creative Commons Attribution License, which permits unrestricted use, distribution, and reproduction in any medium, provided the original author and source are credited. 
4. Kwun DJ, Oh H (2007) Consumers' evaluation of brand portfolios. International Journal of Hospitality Management 26: 81-97.

5. O'Neill JW, Mattila AS (2010) Hotel brand strategy. Cornell Hospitality Quarterly 51: 27-34.

6. King C, Funk DC, Wilkins $H$ (2011) Bridging the gap: An examination of the relative alignment of hospitality research and industry priorities. International Journal of Hospitality Management 30: 157-166.
7. Hsu CH, Oh H, Assaf AG (2012) A customer-based brand equity model for upscale hotels. Journal of Travel Research 51: 81-93.

8. Tasci AD, Guillet BD (2011) It affects, it affects not: A quasi-experiment on the transfer effect of co-branding on consumer-based brand equity of hospitality products. International Journal of Hospitality Management 30: 774-782.
Submit your next manuscript and get advantages of OMICS Group submissions

\section{Unique features:}

- User friendly/feasible website-translation of your paper to 50 world's leading languages

Audio Version of published paper

Digital articles to share and explore

Special features:

200 Open Access Journal

15,000 editorial team

21 days rapid review process

- Quality and quick editorial, review and publication processing

- Indexing at PubMed (partial), Scopus, DOAJ, EBSCO, Index Copernicus and Google Scholar etc

- Sharing Option: Social Networking Enabled

- Authors, Reviewers and Editors rewarded with online Scientific Credits

Befter discount for your subsequent articles

Submit your manuscript at: http://www.omicsonline.org/submission 